\title{
Development of Total Hip Joint Replacement Prostheses Made by Local Material: An Introduction
}

\author{
Tresna Priyana Soemardi ${ }^{*}$, Agri Suwandi², Cholid Badri ${ }^{3}$, Anwar Soefi Ibrahim ${ }^{4}$, \\ Sastra Kusuma Wijaya ${ }^{5}$, and Januar Parlaungan Siregar ${ }^{6}$ \\ ${ }^{1}$ Department of Mechanical Engineering, Faculty of Engineering, Universitas Indonesia, Jl. \\ Kampus UI, Depok, Jawa Barat, 16424 Indonesia \\ ${ }^{2}$ Department of Mechanical Engineering, Faculty of Engineering, Universitas Pancasila, Jl. Raya \\ Lenteng Agung, Jakarta Selatan, 12630 Indonesia \\ ${ }^{3}$ Department of Radiology, Faculty of Medicine, Universitas Indonesia, Jl. Salemba Raya, Jakarta \\ Pusat, 10430 Indonesia \\ 4Department of Medical Physics, Faculty of Medicine, Universitas Indonesia, J1. Salemba Raya, \\ Jakarta Pusat, 10430 Indonesia \\ ${ }^{5}$ Department of Physics, Faculty of Mathematics and Natural Science, Universitas Indonesia, \\ Pondok Cina, Beji, Depok, Jawa Barat 16424 Indonesia \\ ${ }^{6}$ Faculty of Mechanical and Automotive Engineering Technology, Universiti Malaysia Pahang, \\ 26600 Pekan, Pahang, Malaysia
}

\begin{abstract}
Total Hip Joint Replacement Surgery is the procedure of surgical removal of cartilage in the hip joints damaged by disease osteoarthritis to replaced with artificial components. Total Hip Joint Replacement has been indicated to relieve pain in the pelvis due to degenerative joint disease. In Indonesia, this procedure has been practised, but due to the cost of expensive products resulting in limited only to upper classify patients. The high prices caused by importing prostheses products, the technological capabilities and the difficulty to meet the standards of medical devices. The regulation of the Minister of Health of the Republic of Indonesia Number 52, 2016 for standard rates in organising health services Health Assurance Program, explained that the action of these operations entered into the insurance claims BPJS program, but not for the prostheses. This paper discusses the introduction of the development of the hip joint prostheses made from a local material that's SS 316L, PEEK and Ceramic Dental Stone. The result of this development is the product of the hip joint prostheses has a reasonable price with good quality so that it can become affordable for middle to lower patients.
\end{abstract}

Keywords: Ceramic dental stone, degenerative joint disease, rapid manufacturing, stainless steel $316 \mathrm{~L}$, polyetheretherketone.

\footnotetext{
*Corresponding author: tsoemardi@eng.ui.ac.id
} 


\section{Introduction}

Prostheses are commonly applied to replace lost body parts by trauma, congenital or to complete missing body parts. Prostheses can also be utilized as replacements for damaged body parts. Arthritis is one of the joint diseases that many use prostheses, namely Osteoarthritis (OA) and Rheumatoid Arthritis (RA) [1]. Arthritis or arthritis can inflict damage in such a way that it causes the joint to be impossible to perform its function [2]. OA is a disease of the joints where there is damage or loss of cartilage or cartilage. Cartilage is a protein compound that serves as a "cushion" between the bones of the joints [3]. While RA is a chronic inflammatory disorder that usually affects the small joints in the hands and feet.

According to Liddle et al. [4], $89 \%$ of OA patients are present in the elderly or over $50 \mathrm{yr}$, while RA can be infected at all ages, but the most common are at age $40 \mathrm{yr}$ and older in women $[1,5]$. In contrast to the damage to the OA, RA can affect the lining of the joints that causes painful swelling and can ultimately result in bone erosion and deformation of the joints, making it difficult to do the replacement with prostheses [1, 6]. The type of OA that is mostly replaced with prostheses is primary OA and secondary OA due to obesity [2].

One part of the body that is often exposed to OA or RA is the hip joint which is the most dominant part of the role at the same time very susceptible to accidents. The hip joint is the joint support of the body that serves to accommodate the weight of the body while maintaining the level of mobility and stability, specific shape to the size of the connection to show its ability to anticipate movement.

The prostheses of the hip joint are the most common joint replacement. Normal function hip joints, hip joint prostheses design, and related complications have been numerously studied, compared to other joints. The purpose of this paper is to provide preliminary information on research and design development as well as the type of material for the hip joint prostheses.

\section{Research and development}

\subsection{Total hip joint replacement}

The artificial hip joint system is an artificial hip joint system used in total hip replacement. The hip joint is the joint of bone in the femur (femur) with pelvic bone as shown in Figure 1 (a). Total hip replacement or hip joint replacement surgery is usually caused by several things such as age factors, accidents, nutritional deficiencies and bone disease (arthritis).

In total hip replacement also called total pelvic artery, damaged bones and cartilage are removed and replaced with prosthetic components (see Figure 1 (b)). There are four implant components for total hip replacement, which is an acetabular cup, acetabular shell (plastic liner), femoral head, femoral stem. Femoral head with the metal material in hip prostheses replaces the function of the femoral head bone. Acetabular shell component made of plastic or ceramic must be friction resistant, because of friction with a femoral head made of a metal material. 


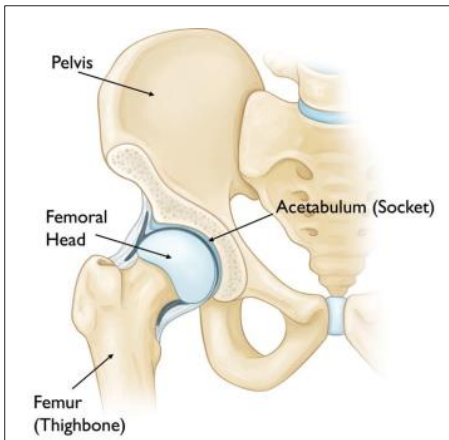

(a). Normal hip anatomy
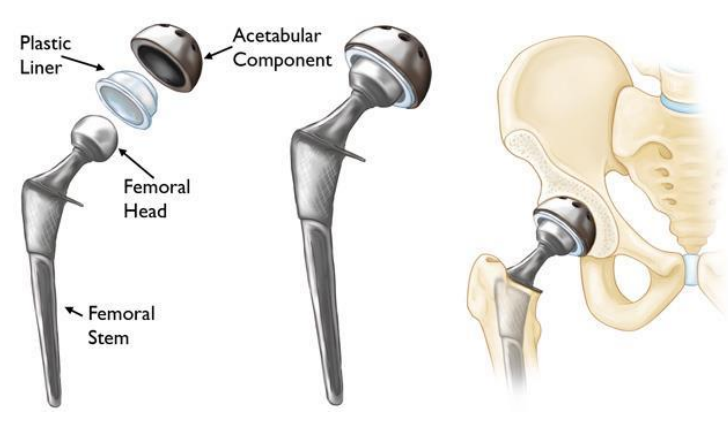

(b). Hip prostheses

Fig. 1. Total hip joint replacement [7].

\subsection{Roadmap of development}

In general, hip bearing in artificial hip joint replacement is classified into (i) hard on hard material such as metal on metal (MOM), ceramic on ceramic (COC) and developed ceramic on metal (COM) and (ii) hard on soft material with using conventional or highly crosslinked UHMWPE as hip bearing, while the femoral head is made of metal alloy (M-PE) or ceramic biomaterial (C-PE).

Development of total hip joint replacement prostheses made from local material in five steps is (see Figure 2): (i) Selection and testing of material composition (metal, plastic and ceramics); (ii) Model of design hip prostheses; (iii) Manufacturing design; (iv) Manufacturing and mechanical testing; and (v) Clinical testing.

The selection and testing of the material composition consist of three types of materials, namely: metal, plastic and ceramics. The metal material is used for stem components and parts of the acetabulum shell of the hip prostheses. The plastic material is used for linear acetabulum parts, while ceramic material is used for the femoral head. Other than ceramic material, for the femoral head component can use the metal material.

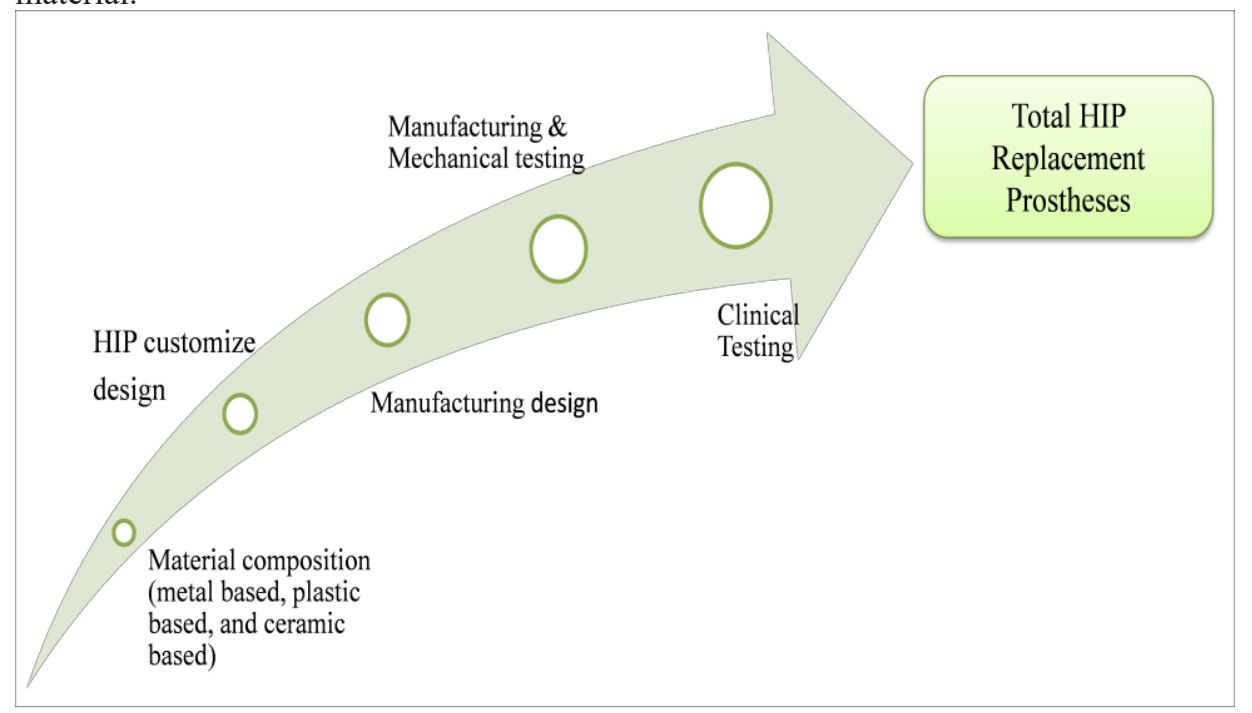

Fig. 2. Step of development. 
In this paper will introduce materials that have the possibility to do the development, special local materials. The purpose of using local materials is to lower material costs for the price of hip prostheses products to be more affordable.

\section{Discussion}

\subsection{Materials combinations}

Many studies state that the selection of metal materials is the most appropriate. But in reality, in implant products or prostheses, a combination of not only metallic material but also non-metallic material is needed. Biocompatible material in an implant is the most critical requirement. Various combinations of materials are combined to get the right characteristics.

The body's ability to accept foreign objects (implants or prostheses) is not only an antibody problem, but the content and material characteristics of the product can influence it. Many cases occur postoperatively, due to incompatible materials which can cause infections of part of the body to the death of the patient. Based on this, many researchers developed various combinations of materials for implant or prostheses products.

According to Suwandi et al., that the criteria of hip joints prostheses must be following requirements [8]: can withstand high dynamic loads; can provide facilities for the body to make movements; can absorb shock, and can maintain body stability. After the criteria aspects of the total hip replacement are fulfilled, then what needs to be considered is the material prostheses aspect, according to Suwandi et al. [8, 9], are: resistance to corrosion; material strength; good formability; suitability to the body; and based on function.

Based on the literature [8], five types of metal material are using in the manufacture of femoral stem components, femoral heads, acetabular components, namely: $\mathrm{Co}-\mathrm{Cr}$, $\mathrm{Ti}$, Ceramic, NiTi and SS316L. Whereas for plastic liner components, there are 2 (two) types of non-metallic material that are widely used, namely: UHMWPE and Crosslinked Polyethylene.

For femoral stem components, 39\% mostly use Co-Cr material, $26 \%$ use Ti material, $17 \%$ use Ceramic material, the remaining 9\% use NiTi and SS316L material. As for the femoral head component, $46 \%$ used Co-Cr material, 38\% used Ti material and $15 \%$ used SS316L material. But for Ceramic and NiTi materials, there is no extensive research on the use of these materials for acetabular components.

In the development, manufacture of components of hip prostheses using casting technology, machining and injection moulding. Femoral components made of metal stem using casting and machining technology. While acetabulum cup using machining technology. The femoral head, in research, conducted using metal and ceramic materials, so the technology used is casting ceramics and or machining. Acetabulum shell component made of plastic material is made using injection moulding technology.

Total hip replacement generally requires the top the femur is replaced and mated pelvic area (hip bone) replaced or reappeared. As shown in Figure 1, a typical hip prostheses is composed of the femoral stem, the femoral sphere, and a polymers (ultrahigh molecular weight polyethene, or UHMWPE) socket (cup) with or without metal support. Femoral Components usually made from Co-Cr-Mo or Co-Ni-Cr-Mo alloys or titanium alloys. Femoral head (articulating section of the femoral component) is made one of them Co-Cr alloy is very smooth or from ceramic (e.g., alumina). Acetabulum shell, where rods and balls are two different materials, i.e. general. For 
example, hip replacement featuring a titanium alloy femoral rod will have a $\mathrm{Co}-\mathrm{Cr}$ femoral head. As well as, UHMWPE sockets of general acetabulum shell replacement can be embedded directly on pelvic or become part of a modular arrangement where the cup is placed into a metal shell. Table 1 shows the combination of materials in the hip component between the femoral head and acetabulum shell (plastic liner) literature review by Suwandi [8].

Based on Table 1, the combination of CoCr and UHMWPE is still in the good category, but the use of $\mathrm{CoCr}$ is starting to the reduced content of carbon because many develop complications in the body of most patients. The development carried out; the $\mathrm{Co}-\mathrm{Cr}$ material will be replaced by SS $316 \mathrm{~L}$ material that is more adaptable to the patient's body condition has a better tensile strength than Co-Cr. The addition of Mo and reduction of carbon content is expected to add strength and biocompatible.

Table 1. Materials combinations in total hip replacement prostheses [8].

\begin{tabular}{|c|c|c|}
\hline Femoral Head & Acetabulum shell & Results \\
\hline Co-Cr-Mo & Co-Cr-Mo & Early loosening rate and limited, lower rate \\
\hline Co-Cr-Mo & UHMWPE & Widely employed, low wear \\
\hline Alumina/zirconia & UHMWPE & $\begin{array}{c}\text { Very low wear, with added zirconia it's more } \\
\text { impact resistance }\end{array}$ \\
\hline Alumina & Alumina & $\begin{array}{c}\text { Minimum wear rate } \\
\text { Ti-6Al-4V }\end{array}$ UHMWPE \\
\hline $\begin{array}{c}\text { Surface-coated } \\
\text { Ti-6Al-4V }\end{array}$ & UHMWPE & $\begin{array}{c}\text { Enhance wear resistance to abrasion, only thin } \\
\text { layer achieved }\end{array}$ \\
\hline
\end{tabular}

The bearing material in the total joint prostheses subject to a very demanding environment because repeated loading under high strength. For hip replacement, the pair of pads is composed of articulating the metallic femoral head against the UHMWPE acetabular cup (see Figure 1). Any use of the connection, such as running, in this case from the hips or knees, resulting in a cyclic articulations polymer cup against metal or ceramic ball.

Due to the significant local contact pressure on the sphere interface / socket, a small area on UHMWPE tends to stick to metal or ceramic ball. During reciprocating motion from the use of normal joints, fibrils will be taken off regions adhered to polymer surfaces and broken to form submicrometer wear debris [9]. This adhesive mechanism, combined with fatigue associated with fatigue UHMWPE (most common in knee joints), produce billions of tiny polymer particles spill liquid and synovial tissue around it.

Biological interactions with small particles in the body then become critical. That the immune system strives, does not work, such as will a bacteria or viruses. An enzyme released it ultimately resulting in an adjacent bone mortality cells, or osteolysis. Over time, enough bone absorbs around the implant to cause mechanics loosening, which requires expensive and costly replacement of painful implants or revisions. Research has indicated that the conditions of contact and material parameters significantly affect the size and form of UHMWPE wear particles [10]. 
Efforts are being made in both academia and industry to reduce wear by using improvements in sterilization and manufacturing techniques, in Indonesia concerts with modification and material development. The use of polymer-on-ceramic and the ceramic-on-ceramic system is also being explored. UHMWPE wear rate against wellpolished alumina appears to be lower compared to the metals currently in use in orthopaedic implants. In the development of this research will try to be replaced UHMWPE with a polyetheretherketone (PEEK) material that has the ease of its manufacturing process nature of a biocompatible, strong, non-corrosive, stable and not affected by high temperatures [11].

The ceramic materials described in this section fall into two broad categories: implant materials and dental porcelains that have the general composition of vitrified feldspar along with additions of metallic oxide pigments that simulate natural tooth enamel shades. Dental porcelains can be classified according to their fusion temperature, application, fabrication technique, or crystalline phase.

In the research that will be done the use of ceramic material for the femoral head, the component is possible. Two-body abrasion of the dental stone has the highest hardness and the lowest loss in two-body abrasion. Although the dental stone is harder than the ceramic resins, the surface morphology of the stone makes it less abrasion resistant.

\subsection{Latest developments}

\subsubsection{Metal}

The mechanical properties of the material influence the characteristics of metal material for prostheses. Alloy is the first choice in producing prostheses components. Not only are the chemical and physical properties present in the material, but the microstructure is important. The strength of the material influenced by the size of the grain structure.

The implant material used in total hip replacement products includes stainless steel, $\mathrm{CoCr}$ and Titanium alloys. Many types of stainless steel have different chemical composition and microstructure. In biomedical applications, various kinds of stainless steel are SS316L.

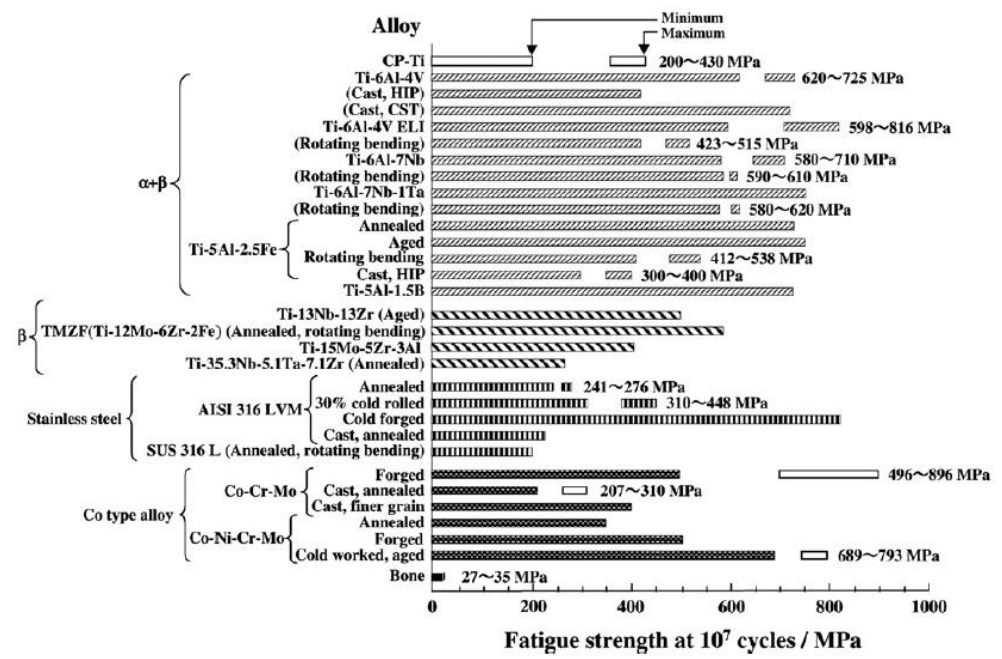

Fig. 3. Fatigue strength of various metallic biomedical materials [12]. 
Figure 3. shows the composition and fatigue strength of various metallic biomedical materials. Can be seen that the average material composition has an element of $\mathrm{Cr}$, Ni, Mo and Ti. It's proves that these elements have a role in determining mechanical properties. In this study using SS316L as local material. The SS316L alloy material content consists of $17 \%$ to $19 \% \mathrm{Cr}, 12 \%$ to $14 \% \mathrm{Ni}$ and $2 \%$ to 3\% Mo. Based on Figure 3, the fatigue strength of the bone around 27-36 MPa, whereas SS316L material around $200 \mathrm{MP}$ or five times as much. Therefore, using stainless steel for bone implants that hold the load, but the protective effects of stress must consider.

\subsubsection{Ceramics}

The use of material bioceramics containing calcium and phosphate is widely used. The reason the use of the material is its content that is similar to the bone, so it has high compatibility. Another is to zirconia that can increase the value of the fracture toughness, and flexural strength was good with Young's modulus values lower. The ability is excellent to use implants or prostheses for bearing parts.

An example of dense synthetically derived hydroxyapatite is given in Table 2 . The ceramic materials described in this section fall into two broad categories: implant materials and dental porcelains that have the general composition of vitrified feldspar along with additions of metallic oxide pigments that simulate natural tooth enamel shades. Dental porcelains ore dental stone can be classified according to their fusion temperature, application, fabrication technique, or crystalline phase.

Table 2. Mechanical properties of oxide ceramic materials used in biomedical applications.

\begin{tabular}{|l|c|c|c|c|c|}
\hline \multicolumn{1}{|c|}{ Property } & $\begin{array}{c}\mathbf{Z r O}_{2} \\
\text { (Y-TZP) }\end{array}$ & $\begin{array}{c}\text { ZrO2 } \\
\text { (Mg-PSZ) }\end{array}$ & $\begin{array}{c}\mathbf{Z r O}_{2} \\
\text { toughened } \\
\text { Al2O3 (ZTA) }\end{array}$ & $\begin{array}{c}\mathbf{A l}_{2} \mathbf{O}_{3} \text { matrix } \\
\text { composite } \\
\text { (AMC) }\end{array}$ & $\begin{array}{c}\text { Dense } \\
\text { Hydroxyapatite } \\
\text { (HA) }\end{array}$ \\
\hline $\begin{array}{l}\text { Bending } \\
\text { strength (MPa) }\end{array}$ & 1000 & 800 & 912 & 1150 & 20 to 80 \\
\hline $\begin{array}{l}\text { Compressive } \\
\text { strength (MPa) }\end{array}$ & 2000 & 1850 & - & 4700 & 100 to 900 \\
\hline $\begin{array}{l}\text { Young s } \\
\text { modulus (GPa) }\end{array}$ & 150 & 208 & 285 & 350 & 70 to 120 \\
\hline Hardness (HV) & 1200 & 1120 & 1500 & 1975 & 500 to 800 \\
\hline
\end{tabular}

\subsubsection{Polymers}

Polymers materials or types of polyethene or plastic materials used for the implant category, are:

1. Poly (methyl methacrylate) or PMMA is the most widely used polymer material in various components of any product included in the health field, for example in contact lenses and orthoses. The advantage of this material is the compatibility with the immunity of the human body.

2. Ultra High Molecular Weight Polyethylene (UHMWPE) is the material most widely used in a combination of implantable components or prostheses, such as knee joints, hip joints and spine. The advantage of this material is that it has the high friction-resistant ability, so it is widely used in implants that rub against each other, whether between metals or ceramics.

3. PolyEtherEtherKetone (PEEK) material is a semi-crystalline linear polycyclic thermoplastic material that is widely used in dentistry. The weakness of this material is the need for a surface treatment process in order to have a better mechanical characteristic value. 
In this study, several mechanical property values are needed to prove whether the polymer material is suitable for use as an implant that is resistant to tensile. Tensile test samples follow ASTM E8 standards.

Table 3. Tensile test result of polymer materials for load-bearing applications.

\begin{tabular}{|l|c|c|c|}
\hline \multicolumn{1}{|c|}{ Property } & UHMWPE & PMMA & PEEK \\
\hline Young's modulus (GPa) & 0.8 to 2.7 & 3.3 & 3.6 \\
\hline Tensile strength (MPa) & 40.98 & 79.98 & 91.92 \\
\hline Elongation at break (\%) & 449.97 & 5.53 & 49.89 \\
\hline Water uptake at $20^{\circ} \mathrm{C}(\%)$ & 0.009 & 0.347 & 0.592 \\
\hline
\end{tabular}

From Table 3, that the type of PEEK material has an optimal test value for tensile strength, this can be used as a reference for the development of PEEK material for prosthesis hip joint replacement components.

\section{Conclusion}

In this paper has shown the alternative material for total hip joint replacement prostheses product like SS 316L, PEEK and Ceramic Dental Stone, but to ensure the strength will be tested for advance mechanical test and clinical test. The use of local materials in Indonesia is expected to improve the industry's ability in providing quality raw materials for medical equipment products.

Research, design and development activities by the author mention in this paper have been supported by the research grant 'Penelitian Terapan Unggulan Perguruan Tinggi', contract number 008/KM/PNT/2018 from the Ministry of Research Technology and Higher Education of the Republic of Indonesia and DRPM Universitas Indonesia with letters of agreement implementation research number 511/UN2.R3.1/HKP05.00/2018.

\section{References}

1. A.L. Stevens, B. Gharaibeh, K.R. Weiss, F.H. Fu, J. Huard. Gene therapy in the treatment of knee disorders. In: Insall \& scott surgery of the knee. Philadelphia: Churchill Livingstone (2012). p.e4-1-e4-31. https://www.researchgate.net/publication/284347948_Gene Therapy in the Treat ment_of_Knee_Disorders

2. P.B. Rosenthal. Knee osteoarthritis. In: Insall \& scott surgery of the knee. Philadelphia : Churchill Livingstone (2012). p.718-722.

https://books.google.co.id/books?id=ujIUjjqajNEC\&pg=PR33\&lpg=PR33\&dq=Ro senthal. + Knee + Osteoarthritis\&source $=$ bl\&ots $=$ h-

NZPtRQsD\&sig=ACfU3U1dliuZhPOMlBEVdJbKtSapfOb9dQ\&hl=en\&sa=X\&ve d=2ahUKEwjH-

Zf43ObiAhVNSX0KHfHRBugQ6AEwDHoECAgQAQ\#v=onepage\&q=Rosenthal. $\% 20 \mathrm{Knee} \% 20$ Osteoarthritis\&f=false 
3. N. Palastanga, D. Field, R. Soames. Anatomy and human movement: Structure and function. 4nd ed. London: Butterworth-Heinemann (2002).

https://www.amazon.com/Anatomy-Human-Movement-Palastanga-ButterworthHeinemann/dp/B008ITTXXU

4. E.A.D. Liddle, C. Pegg, H. Pandit. Maturitas, 75,2:131-136(2013). https://www.ncbi.nlm.nih.gov/pubmed/23582106

5. J. Wilkinsona, P. Haslamb, C. Getty. Current Orthopaedics, 21,5:330-339(2007). https://www.researchgate.net/publication/246836654_Hip_and_knee_reconstructio $\mathrm{n}$ in the rheumatoid patient

6. M.A. Ritter, J.D. Lutgring, K.E. Davis, P.M. Faris, M.E. Berend. The Knee, 14,1:9-11(2007). https://www.ncbi.nlm.nih.gov/pubmed/17169563

7. American Academy of Orthopaedic Surgeons, Treatment total hip replacement [Online] from https://orthoinfo.aaos.org/en/treatment/total-hip-replacement/ (2015). [Accessed 11 july 2018].

8. A. Suwandi. Pengembangan perancangan dan manufaktur customized prostheses yang lebih cepat untuk penggantian total sendi lutut [Development of fast customized prostheses design \& manufacturing for total knee replacement] [Dissertation] Fakultas Teknik, Universitas Indonesia, Depok (2017). [in Bahasa Indonesia]. https://eng.ui.ac.id/blog/doktor-ftui-kembangkan-sendi-lutut-buatan/

9. A. Suwandi, T.P. Soemardi, G. Kiswanto, W. Kusumaningsih, I.G.W. I Gusti Development of friction and wear full-scale testing for TKR prostheses with reliable low cost apparatus. International Symposium on Biomedical Engineering 2017 (Denpasar, Indonesia, 2017). https://aip.scitation.org/doi/10.1063/1.5023937

10. M.M. Ardestani, P.P.A. Edwards, M.A. Wimmer. Clin. Orthop. Relat. Res., 475,8:2027-2042(2017). https://www.ncbi.nlm.nih.gov/pubmed/28255945

11. A.S. Ibrahim, C. Badri, B.S. Latief, S.K. Wijaya, V. Sutarmo, A. Suwandi. Aiti, 14,2:150-155(2017). http://ejournal.uksw.edu/aiti/article/view/1363

12. M. Niinomi. International Journal Fatigue, 29(6):992-1000(2007). https://www.sciencedirect.com/science/article/pii/S0142112306002799 